\title{
Diagnosing Kaposi's Sarcoma (KS) in East Africa: how accurate are clinicians and pathologists?
}

\author{
Erin Amerson ${ }^{1 *}$, Nathan Buziba ${ }^{2}$, Henry Wabinga ${ }^{3}$, Megan Wenger ${ }^{1}$, Mwebesa Bwana ${ }^{4}$, Winnie Muyindike ${ }^{4}$, \\ Catherine Kyakwera ${ }^{4}$, Miriam Laker ${ }^{5}$, Edward Mbidde ${ }^{5}$, Constantin Yiannoutsos ${ }^{6}$, Kara Wools-Kaloustian ${ }^{6}$, \\ Beverly Musick ${ }^{6}$, Philip LeBoit ${ }^{1}$, Tim McCalmont ${ }^{1}$, Beth Ruben ${ }^{1}$, Paul Volberding ${ }^{1}$, Toby Maurer $^{1}$, Jeffrey Martin ${ }^{1}$ \\ From 13th International Conference on Malignancies in AIDS and Other Acquired Immunodeficiencies \\ (ICMAOI) \\ Bethesda, MD, USA. 7-8 November 2011
}

\section{Background}

HIV-associated KS is the most common reported malignancy in sub-Saharan Africa, and appropriate therapy of KS requires accurate diagnosis. In much of the region, however, KS diagnosis is limited to clinical suspicion without pathologic confirmation. Where pathology is available, specific anti-KSHV stains are rarely available and overall pathologic accuracy for KS has not been evaluated.

\section{Methods}

We introduced skin punch biopsy for KS at HIV/AIDS care clinics in Uganda and Kenya within the East Africa IeDEA Consortium. Clinicians suspecting KS could obtain a biopsy same day without charge. After interpretation by local African pathologists who only had access to routine H\&E staining, biopsies were read by dermatopathologists at UCSF who could, at their discretion, recut and restain specimens or stain against latency-associated nuclear antigen (LANA) of KSHV. The interpretation by the U.S. dermatopathologists, who serve a large base of HIV-infected patients, was considered the gold standard.

\section{Results}

Clinicians at 26 HIV/AIDS clinics in Uganda and Kenya referred 739 patients with clinically suspected KS for skin biopsy. Overall, 77\% (95\% CI: 74\%-80\%) of these clinically suspected cases were determined pathologically to be KS after U.S. review; 19\% had another diagnosis and 4\% were indeterminate. There was no significant difference in the percentage found to be KS between countries $(\mathrm{p}=0.20)$ or over time $(\mathrm{p}=0.11)$. When KS was not found, a wide variety of other diagnoses, both clinically significant and insignificant, were made by the U.S. dermatopathologists (Table 1). Two different pathology services, one in Uganda one in Kenya, submitted biopsies for review by U.S. dermatopathologists. Overall concordance between African and U.S. interpretations was $71 \%$ (95\% CI: $68 \%-74 \%)$. When the U.S. interpretation was considered gold stan-

Table 1

\begin{tabular}{llll}
\hline \multicolumn{4}{l}{ Sample of pathologic diagnoses made by U.S. dermatopathologists } \\
\hline Scar $(\mathrm{n}=9)$ & Post-inflammatory KS was not present & Lymphoma (5) \\
\hline Wart (5) & Bacillary angiomatosis (4) & Psoriasis (8) & Sarcoidosis (2) \\
\hline Polyarteritis nodosa (2) & Pyogenic granuloma (2) & Morphea (4) & Lichen planus (2) \\
\hline Dermatofibroma (2) & Castleman's Disease (1) & Mycobacterial dermatitis (2) & Deep fungal infection (1) \\
\hline Secondary syphilis (1) & Erythema multiforme (1) & Squamous cell carcinoma (1) & Xanthoma (1) \\
\hline
\end{tabular}

\footnotetext{
* Correspondence: amersone@derm.ucsf.edu

'University of California, San Francisco, USA

Full list of author information is available at the end of the article
} 
dard, sensitivity of the African pathologic interpretation for KS was $72 \%$ and specificity $84 \%$. Over time, sensitivity increased at one African center $(\mathrm{p}=0.04)$ but decreased in another $(\mathrm{p}<0.001)$; specificity increased at one center $(\mathrm{p}=0.001)$ and was unchanged in another $(\mathrm{p}=0.68)$.

\section{Conclusions}

Amongst clinicians at HIV/AIDS clinics in East Africa, clinical suspicion of KS alone is not optimally specific for KS diagnosis. Clinical suspicion alone often either misdiagnoses conditions which are less concerning than KS or misses other serious conditions that require different therapy than KS. Assuming the U.S. interpretation is the gold standard, pathologic determination of $\mathrm{KS}$ in East Africa is specific but not optimally sensitive. The findings urge for increased availability of skin punch biopsies for KS diagnosis in Africa and augmentation of pathology services.

\section{Author details}

${ }^{1}$ University of California, San Francisco, USA. ${ }^{2}$ Moi University, Eldoret, Kenya. ${ }^{3}$ Makerere University, Kampala, Uganda. ${ }^{4}$ Mbarara University of Science and Technology, Mbarara, Uganda. ${ }^{5}$ Infectious Diseases Institute, Kampala,

Uganda. ${ }^{6}$ Indiana University, Indianapolis, IN, USA.

Published: 19 April 2012

doi:10.1186/1750-9378-7-S1-P6

Cite this article as: Amerson et al.: Diagnosing Kaposi's Sarcoma (KS) in East Africa: how accurate are clinicians and pathologists? Infectious Agents and Cancer 2012 7(Suppl 1):P6.

\section{Submit your next manuscript to BioMed Central} and take full advantage of:

- Convenient online submission

- Thorough peer review

- No space constraints or color figure charges

- Immediate publication on acceptance

- Inclusion in PubMed, CAS, Scopus and Google Scholar

- Research which is freely available for redistribution

Submit your manuscript at www.biomedcentral.com/submit 